the accoucheur when unfortunately he has had to deal with a case of the kind, by his going into a small apartment, placing a few scales of iodiue on a saucer, and holding beneath it a suirit-lamp for a few seconds, when he will be surrounded by the beautiful violet-coloured fumes of iodine, and may then go without dread or fear and attend any other female in her confinement, the septic poison having been converted into harmless carbon.

I remain, Sir, yours faithfully,

A. WYNN WILLIAMS, M.D.

Montagu-square, February 8 th, 1882.

\section{"THE RECENT FOGS."}

To the Editor of THE LANCET.

SIR, - I would respectfully ask permission to express dissent from your dictum, that "smoke and fog have little in common." Allow me to state the following facts in support of my objection.

On the morning of January 2 lst of this year I noticed that the surface of a piece of water in my grounds was covered with a grey scum. Of this I skimmed off a small portion, which on examination with the microscope I found to consist of minute particles of soot. On the previous evening a change of wind had brought over from the direction of London a dense black fog, the source, I believe, of the film of dirt on the pond.

I observed a very similar occurrence several years ago in Upper Holloway. On one winter's day we had a heavy fall of snow which lay thick on the ground. On the same evening there came on a downright thick, peasoup fog: the next morning the pure white mantle of snow had become of a dirty brown colour from the smoke and soot deposited thereon from the fog.

I believe that many housekeepers in London and other large cities can testify to the dirt left upon curtains and window-blinds by thick fogs. Moreover, I would beg leave to state that my recollections do not correspond with yours as to the amount of fog in London in former, as compared with later, years. My memory carries me back, as a denizen of the city, beyond the "thirties or 'forties," to the "twenties"; but I have no remembrance of any fogs in London worse than, or even so bad as, some that we have recently experienced. Forty-four years of practice in the northern metropolitan districts would lead me to say that fogs have increased in density with the increase of buildings in the suburbs.

I remain, Sir, your obedient servant,

Enfield, Feb. 13th, 1882.

W. B. Kesteven, M.D.

* No one can doubt that fogs are dirty, and that, as the floating dirt of a city atmosphere is chiefly soot, fogs occurring in a city will generally be laden with soot; but this is a vastly different story from that which makes smoke the cause of fogs! As regards the observations and experience of our correspondent, which so greatly differ from our own, we can only adhere to the opinion which we have previously expressed.-ED. L.

\section{PHTHISIS AND INFECTION. To the Editor of THE LANCET.}

SIR,-May I solicit a short space in your columns to reply to Dr. Dale's letter published in to-day's issue. Although it bristles with quire a formidable array of quotations, a great part of Dr. Dale's communication simply denies the correctness of the views adduced in my paper, and does not require further comment. One or two points, however, demand brief notice.

Referring to the production of tuberculosis by the introduction of tubercular matter into the alimentary canal, Dr. Dale says that other putrefying or septic substances introduced into the healthy body will produce pathological appearances which cannot be distinguished from those which accompany phthisis. I was not aware until to-day that the tubercular virus was either putrefying or septic. Cohnheim says that it is important that the virus should be fresh and free from taint, lest the experiment be affected by septic and other intluences. I know that inoculation with cheese, brain, \&c., has produced anatomical changes somewhat similar to those observed in tuberculosis. But with these anatomical appearances all resemblance ceases. Yet even admitting the truth of Dr. Dale's statement, I fail to see how it affects my argument. Moreover, Dr. Dale now acknowledges that the healthy body may be infected by the introduction of tubercular matter into the alimentary canal. He therefore admits the truth of the statement which in his previous letter he singled out of my communication to refute. No phy. sician attempts to claim for tuberculosis the same infective power that the eruptive fevers posse:s ; so that Dr. Dale's comparison is useless.

Dr. Dale terms Lister's germ theories "strange mistakes." They may be so ; but it was upon this "fulse analogy," and this " unverified hypothesis," that Lister founded his grand principles of treatment which have revolutionised surgery. Dr. Dale's observations on Lister's doctrines and on contagion should be read along with his concluding remarks on phthisis in his former letter. It would be interesting to learn his views upon other current medical topics.

As I mentioned in my previous letter, I have met with other cases than those narrated which could only be explained by the theory of infection; but $\Gamma$ adduced those two because they were supported by the opinion of gentlemen who rank deservedly high in the profession. Dr. Dale, however, has not met with similar cases; therefore, de facto, these authorities are wrong.

I am, Sir, yours truly

A. M. M'AlDowie, M.D.

Stoke-upon-Trent, Feb. 11th, 1882,

\section{"ISOLATION IN RINGWORM CASES NOT NECESSARY." \\ To the Editor of THE LANCET.}

SIR,-On reading the heading of Dr. Thin's letter, and also the first paragraph of it, I was inclined to hope that at last some real improvement in the treatment of ringworm had been discovered.

That cases of ringworm of the scalp should be allowed to remain in schools without risk of the disease spreading, and that, in consequence, the children would not have education interfered with, is a matter of such vital importance, that parents and schoolmasters will be indeed grateful to Dr. Thin if his plan is successful.

As I advanced towards the end of the letter, my hopes that a solution of this difficult and complex subject had bcen found were somewhat shaken by the fact, that the plan suggested by Dr. Thin showed no signs of novelty. All things that are new are not true, has been said ; still one hoped for something new, because the old system of covering the patches with ointments of various kinds has been tried for years in the schools of Eagland, and with what success every medical officer knows full well.

I am, Sir, your obedient servant,

Montagu-square, Feb. 14th, 1882.

MALCOLM MORRIS.

\section{PHOSPHORUS NECROSIS. To the Editor of THE LANCET.}

SIR,-During four months in which I fulfilled the duties of house-surgeon to the Children's Hospital, Shadwell, last year, one case of necrosis of the jaw presented itself at the hospital. The patient was a boy of about twelve years, and worked at a well-known match factory. His mother stated she knew of several similar cases that had occurred among employés at this factory. The disease was on the left side of the lower jaw. A grood deal of friable dead bone was removed by operation; and a large piece, about two inches long, afterwards separated spontaueously. The boy had decayed teeth in the left lower jaw.

Mr. Parker, under whose care the case was, refused to consider it phosphorus necrosis on account of the extreme rarity of that disease, of its very localised character, and because only amorphous phosphorus was reputed to be used at the factory in question. At any rate, the case seems to lend weight to Mr. Treves' opin iou that phosphorus necrosis is commoner than is generally suprosed. I am, Sir, ynurs faithfully, SIDNEY DATIES, B.A., M.P.C.S.

Training Hospital, Tottenham, Feb. 4th, 188? 